NASA/TM-2002-211552

\title{
A Desorbed Gas Molecular Ionization Mechanism for Arcing Onset in Solar Arrays Immersed in a Low-Density Plasma
}

J. Galofaro

Glenn Research Center, Cleveland, Ohio

B. Vayner

Ohio Aerospace Institute, Brook Park, Ohio

D. Ferguson

Glenn Research Center, Cleveland, Ohio

W. Degroot

Siliconlight, Inc., Sunnyvale, California 
Since its founding, NASA has been dedicated to the advancement of aeronautics and space science. The NASA Scientific and Technical Information (STI) Program Office plays a key part in helping NASA maintain this important role.

The NASA STI Program Office is operated by Langley Research Center, the Lead Center for NASA's scientific and technical information. The NASA STI Program Office provides access to the NASA STI Database, the largest collection of aeronautical and space science STI in the world. The Program Office is also NASA's institutional mechanism for disseminating the results of its research and development activities. These results are published by NASA in the NASA STI Report Series, which includes the following report types:

- $\quad$ TECHNICAL PUBLICATION. Reports of completed research or a major significant phase of research that present the results of NASA programs and include extensive data or theoretical analysis. Includes compilations of significant scientific and technical data and information deemed to be of continuing reference value. NASA's counterpart of peerreviewed formal professional papers but has less stringent limitations on manuscript length and extent of graphic presentations.

- TECHNICAL MEMORANDUM. Scientific and technical findings that are preliminary or of specialized interest, e.g., quick release reports, working papers, and bibliographies that contain minimal annotation. Does not contain extensive analysis.

- CONTRACTOR REPORT. Scientific and technical findings by NASA-sponsored contractors and grantees.
- CONFERENCE PUBLICATION. Collected papers from scientific and technical conferences, symposia, seminars, or other meetings sponsored or cosponsored by NASA.

- SPECIAL PUBLICATION. Scientific, technical, or historical information from NASA programs, projects, and missions, often concerned with subjects having substantial public interest.

- TECHNICAL TRANSLATION. Englishlanguage translations of foreign scientific and technical material pertinent to NASA's mission.

Specialized services that complement the STI Program Office's diverse offerings include creating custom thesauri, building customized data bases, organizing and publishing research results ... even providing videos.

For more information about the NASA STI Program Office, see the following:

- Access the NASA STI Program Home Page at http://www.sti.nasa.gov

- E-mail your question via the Internet to help@sti.nasa.gov

- Fax your question to the NASA Access Help Desk at 301-621-0134

- Telephone the NASA Access Help Desk at 301-621-0390

- Write to:

NASA Access Help Desk

NASA Center for AeroSpace Information 7121 Standard Drive

Hanover, MD 21076 
NASA/TM-2002-211552

AIAA-2002-2262

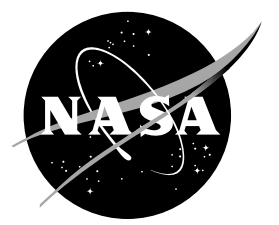

\section{A Desorbed Gas Molecular Ionization Mechanism for Arcing Onset in Solar Arrays Immersed in a Low-Density Plasma}

J. Galofaro

Glenn Research Center, Cleveland, Ohio

B. Vayner

Ohio Aerospace Institute, Brook Park, Ohio

D. Ferguson

Glenn Research Center, Cleveland, Ohio

W. Degroot

Siliconlight, Inc., Sunnyvale, California

Prepared for the

33rd Plasmadynamics and Lasers Conference

sponsored by the American Institute of Aeronautics and Astronautics

Maui, Hawaii, May 20-23, 2002

National Aeronautics and

Space Administration

Glenn Research Center 
Available from

NASA Center for Aerospace Information 7121 Standard Drive

Hanover, MD 21076
National Technical Information Service 5285 Port Royal Road Springfield, VA 22100

Available electronically at http:/ /gltrs.grc.nasa.gov/GLTRS 


\title{
A DESORBED GAS MOLECULAR IONIZATION MECHANISM FOR ARCING ONSET IN SOLAR ARRAYS IMMERSED IN A LOW-DENSITY PLASMA
}

\author{
J. Galofaro* \\ National Aeronautics and Space Administration \\ Glenn Research Center \\ Cleveland, Ohio 44135 \\ B. Vaynert \\ Ohio Aerospace Institute \\ Brook Park, Ohio 44142 \\ D. Ferguson \\ National Aeronautics and Space Administration \\ Glenn Research Center \\ Cleveland, Ohio 44135 \\ W. Degroot ${ }^{\S}$ \\ Siliconlight, Inc. \\ Sunnyvale, California
}

\begin{abstract}
$\underline{\text { Abstract }}$
Previous experimental studies have hypothesized that the onset of Solar Array Arc (SAA) initiation in low-density space plasmas is caused by a desorbed gas molecular ionization mechanism. Indeed past investigations performed at the NASA Glenn Plasma Interaction Facility tend to not only support the desorbed gas molecular ionization mechanism, but have gone as far as identifying the crucial molecular species that must be present for molecular ion dominated process to occur. When electrical breakdown occurs at a triple junction site on a solar array panel, a quasi-neutral plasma cloud is ejected. Assuming the main component of the expelled plasma cloud by weight is due to water vapor, the fastest process available is due to

\footnotetext{
*Physicist, Member AIAA

${ }^{\dagger}$ Senior Scientist, Member AIAA

${ }^{*}$ Senior Scientist, Member AIAA
}

${ }^{\S}$ Senior Researcher, Member AIAA
\end{abstract}

$\mathrm{H}_{2} \mathrm{O}$ molecules and $\mathrm{OH}^{+}$ions, or more succinctly, dissociative molecular-ion dominated recombination processes: $\mathrm{H}_{2} \mathrm{O}^{+}+\mathrm{e}^{-}$ $\rightarrow \mathrm{H}^{*}+\mathrm{OH}^{*}$. Recently published spectroscopic observations of solar array arc spectra in ground tests have revealed the wellknown molecular $\mathrm{OH}$ band (302nm-309nm), as well as the molecular $\mathrm{SiH}$ band $(387 \mathrm{~nm}$ peak) and, the molecular $\mathrm{CH}$ band $(432 \mathrm{~nm}$ peak). Note that the $\mathrm{OH}$ band is observed in emission arcs where water vapor is present. Strong atomic lines were also observed for $\mathrm{H}_{\beta}$ at $486 \mathrm{~nm}$ and $\mathrm{H}_{\alpha}$ at $656.3 \mathrm{~nm}$ in prior ground testing. Independent supporting evidence of desorbed gas molecular ionization mechanisms also come from measurements of arc current pulse widths at different capacitances. We will revisit an earlier first order approximation demonstrating the dependence of arc current pulse widths on the square root of the capacitance. The simple arc current pulse width model will be 
then be used to estimate the temperature of the arc plasma (currently believed to be somewhere in the range of 3 to $5 \mathrm{eV}$ ). The current paper then seeks to extend the outlined work by including numerous vacuum chamber measurements obtained with a quadrupole mass spectrometer. A small solar array was mounted inside the vacuum chamber. A plasma source, also mounted inside the vacuum chamber, is used to simulate a lowdensity plasma environment. The solar array is then biased to a high negative potential and allowed to arc while a mass spectrometer is used to record the partial pressure of $\mathrm{H}_{2} \mathrm{O}$ and to track other significant changes in mass (1-150) AMU.

\begin{tabular}{ll} 
& \multicolumn{1}{c}{ Nomenclature } \\
$C$ & $=$ capacitance, $\mu F$ \\
$\mathrm{~V}_{\mathrm{s}}$ & $=$ spacecraft potential, $\mathrm{V}$ \\
$\mathrm{V}_{\mathrm{p}}$ & $=$ plasma potential, $\mathrm{V}$ \\
$\mathrm{V}_{\mathrm{o}}$ & $=$ array output voltage, $\mathrm{V}$ \\
$U$ & $=$ bias potential, $\mathrm{V}$ \\
$N_{e}$ & $=$ electron number density, $\mathrm{cm}^{-3}$ \\
$T_{e}$ & $=$ electron temperature, $\mathrm{eV}$ \\
$A$ & $=$ atomic molecular mass, AMU \\
$m_{e}$ & $=$ electron rest mass, $\mathrm{kg}$ \\
$k$ & $=$ Boltzmann constant, $\mathrm{J} \mathrm{K}^{-1}$ \\
$e$ & $=$ electron charge, $\mathrm{q}$ \\
$\gamma$ & $=$ recombination rate, $\mathrm{cm}^{3} \mathrm{~s}^{-1}$ \\
$y, x$ & $=$ curve fitted variables \\
$a, b$ & $=$ intercept, slope constants \\
$\tau$ & $=$ pulse width, $\mathrm{s}$
\end{tabular}

\section{Introduction}

The trend for modern day satellite designers is to provide robust high voltage power generation equipment that is both lightweight and arc resistant in the harsh plasma environment of space. Solar arrays are often employed to generate the required power because they fit most of the design criteria set forth above. While older payloads typically operated at less then $80 \mathrm{~V}$, newer payloads are designed to operate at $300 \mathrm{~V}$ or more. The high voltage requirements have placed a heavier demand on modern spacecraft power systems.

Traditionally spacecraft designers have incorporated a single point ground to connect the negative end of the solar array directly to the structure while the entire spacecraft is allowed to electrically float in the space plasma environment. The negative grounding scheme has led to potentially hazardous problems involving arcing [1-5].

If the un-powered spacecraft is allowed to float in the ambient plasma it will float at a potential $\mathrm{V}_{\mathrm{s}}$ close to the plasma potential $\mathrm{V}_{\mathrm{p}}$. Assume for the moment that the spacecraft structure floats at an approximate potential $\mathrm{V}_{\mathrm{p}}=-2 \mathrm{eV}$. Now add a negatively grounded array to the spacecraft structure and assume the array develops an output voltage $\mathrm{V}_{\mathrm{o}}=$ $-300 \mathrm{~V}$. The spacecraft potential is effectively pulled to a potential $\mathrm{V}_{\mathrm{s}} \approx-70 \mathrm{~V}$ [22].

Because the negative end of the solar array is grounded to the spacecraft structure, the metallic contacts of the array will acquire the same spacecraft potential $\mathrm{V}_{\mathrm{s}}$ as the structure. The high negative potential $\mathrm{V}_{\mathrm{s}}$ of the metallic contacts gives rise to a proportionate ion flux to the surface of the solar arrays, causing the individual solar cell cover glass slides to acquire a positive surface charge. Positively charged atoms accelerated towards the metallic contacts, will hit the contact, and release secondary electrons.

Previous experimental investigations have shown that arcs tend occur at the triple junction sites of a solar array. A triple junction site on a solar array is defined as any node where adjacent conductor- dielectric and plasma junctions intersect. The ongoing surface chemistry, due to the adsorption of water molecules by the metallic contacts coupled with secondary electron emission to the side surface of the dielectric, leads to electron impact desorption.

Electron Impact Desorption (EID) is believed to be responsible for ionization of 
$\mathrm{H}_{2} \mathrm{O}$ molecules and the formation of $\mathrm{H}^{*}$ and $\mathrm{OH}^{*}$ [6-12]. Secondary electrons impacting a water vapor molecule causes the molecule to lose an electron and to acquire an overall positive charge: $\left(\mathrm{H}_{2} \mathrm{O}-\mathrm{e}^{-} \rightarrow \mathrm{H}_{2} \mathrm{O}^{+}\right)$Further bombardment of $\mathrm{H}_{2} \mathrm{O}^{+}$molecules by other secondary electron impacts leads to EID and causes dissociative recombination processes to emerge: $\left(\mathrm{H}_{2} \mathrm{O}^{+}+\mathrm{e}^{-} \rightarrow \mathrm{H}^{*}+\mathrm{OH}^{*}\right)$. See Figure 1 for details. Note the time scale for

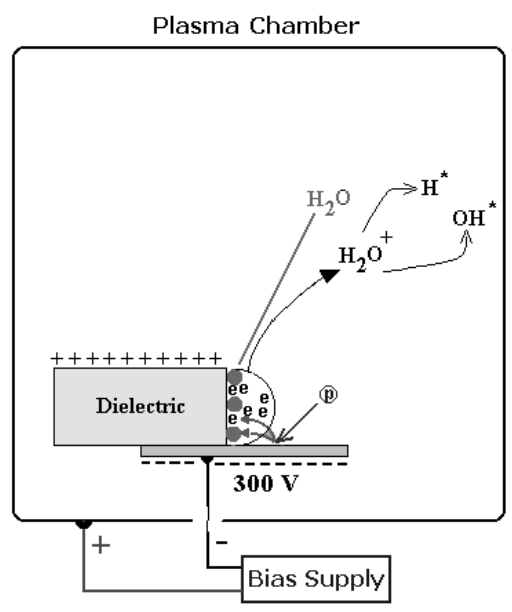

Figure (1): Electron impact ionization is believed to be the leading cause for emergence of dissociative recombination processes.

dissociative recombination processes to occur is of the order of $(8-10) \mu$ s and the distances involved typically range from (1-2) $\mathrm{cm}$. in radius from the triple junction site. Secondary electron emissions also cause the side surface of the cover glass to charge positive (see Figure1). The plasma sheath and mirror side charge are believed to be responsible for the formation of a strong E-field at the triple junction site. Increasing numbers of negative charges continue to build up on the side surface of the cover glass until an ensuing electron avalanche causes the arc to strike.

The scientific community has actively studied the problem of arc initiation and numerous models have been developed to describe the underlying cause of arcing onset in space based solar arrays [13-21]. The so-called triple junction model has previously been employed (with limited success) to explain how the formation of a strong electric field at the metal, dielectric and plasma junctions of a solar array leads to arcing [13-16]. Past work performed at the Glenn Research Center (GRC) lends weight to our hypothesis that condensed water at the triple junction site is responsible for the desorbed gas ionization mechanism and the resulting dissociative molecular-ion recombination processes. The current work seeks to confirm the desorbed molecular gas hypothesis through an independent experimental verification method. The independent verification method used a quadruple mass spectrometer to track changes in the partial pressures of $\mathrm{H}_{2} \mathrm{O}, \mathrm{OH}$ and $\mathrm{H}_{2}$ as well as tracking changes to other mass species during the arcing process.

\section{Energy Estimates of SAA Plasmas:}

Direct evidence supporting a desorbed gas ionization mechanism has come from measurements of arc current pulse widths at different capacitances [16]. The dependence of arc current pulse widths on the square root of the capacitance can be written to a first order approximation as

$$
t=\left(\frac{\gamma \cdot C \cdot U}{\pi \cdot e}\right)^{\frac{1}{2}} \cdot\left(\frac{A \cdot m_{e}}{2 \cdot k \cdot T_{e}}\right)^{\frac{3}{4}}
$$

The dissociative recombination rate $\gamma$ is defined as

$$
\gamma=10^{-7} \cdot \frac{1}{\sqrt{T_{e}}} \mathrm{~cm}^{3} \cdot \mathrm{s}^{-1}
$$

Where $T_{e}$ is the electron temperature of the arc plasma in $\mathrm{eV}$. Taking the atomic mass $(\mathrm{A}=18)$ for the $\mathrm{H}_{2} \mathrm{O}$ molecule and a bias 
potential $\mathrm{U}=500 \mathrm{~V}$ the current pulse width $\tau$ in equation (1) can be rewritten as.

$$
\tau=53 \cdot C^{\frac{1}{2}} \cdot T_{e}^{-1} \quad \mu s
$$

A simple square root approximation of capacitance to arc current pulses width data in equation (4) has yielded good results [16].

$$
y=a+b \cdot \sqrt{x},
$$

Arc Current pulse width vs. Capacitance Fitted to

Square Root Approximatiom for Bias -500 V:

$(\mathrm{y}=\mathrm{a}+\mathrm{b} \sqrt{\mathrm{x}}, \mathrm{a}=4.31095, \mathrm{~b}=11.918383)$

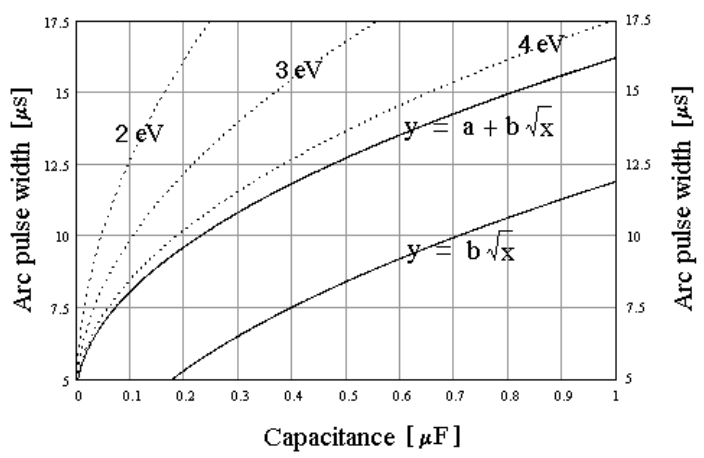

Figure (2): Both solid lower curves were plotted with a value $T_{e}=4.45 \mathrm{eV}$. All other dotted curves are plotted with the values of $\mathbf{T}_{\mathrm{e}}$ indicated.

where: $x$ represents the capacitance in $\mu F$ and $y$ the fitted arc pulse width in $\mu s$. The constants $a, b$ represent the respective $\mathrm{y}$-intercept and slope (see Figure 2). Equations (3) \& (4) can be used to estimate the energy $\mathrm{T}_{\mathrm{e}}$ of the arc plasma by equating the following relations.

$$
53 \cdot C^{\frac{1}{2}} \cdot T_{e}^{-1}=b \cdot \sqrt{x}
$$

Assuming, $x=C$ in equation (5a), we may solve directly for $T_{e}$ to obtain

$$
T_{e}=\frac{53}{b} \cong 4.45 \quad \mathrm{eV}
$$

Figure 2 demonstrates the results obtained by plotting equation (4) at different electron temperatures (The capacitance, $\mathrm{x}$ is used as the running variable and the fitted arc pulse width $y$ is the dependant variable). In Figure 2 the lower solid curve was plotted using equation (4) with the value $a=0$; Letting $b=$ $53 / \mathrm{T}_{\mathrm{e}}$ in equation (4) correctly results in equation (5a). The upper solid line plotted in Figure 2 was obtained using equation (4)

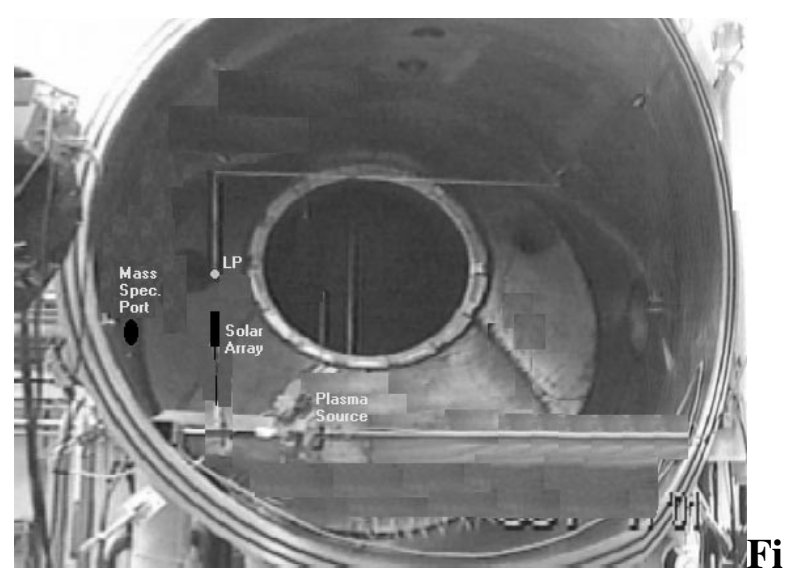

Figure 3: Open view of Tenny vacuum chamber used in tests.

with the fitted values of both $a$, and $b$ shown in Figure 2). It should also be noted that EID stimulated processes require far less energy $(4.45 \mathrm{eV})$ to initiate than what is typically needed to ionize a hydrogen atom $(13.6 \mathrm{eV})$.

\section{Experimental Apparatus}

Ground tests for the mass species investigations were performed in the large ( $2.5 \mathrm{~m}$ long by $1.8 \mathrm{~m}$ diameter) Teney vacuum chamber located at the NASA Glenn Plasma Interaction facility (See Figure 3). A commercially manufactured hollow cathode capable of producing $\mathrm{T}_{\mathrm{e}}=0.7 \mathrm{eV}$ electrons was used as a plasma source for the experiments. Xenon neutral gas for the experiments was carefully metered into the 


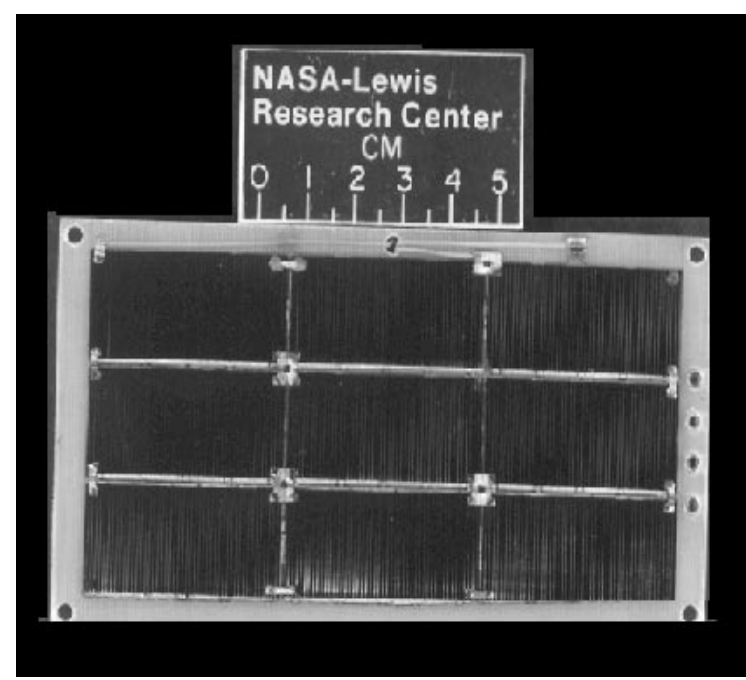

Figure 4: The pictured array is composed of 3 strings wired in parallel. Each string has 3 cells wired in series.

chamber using a precision vacuum valve with variable size orifice. An ionization gauge was then used to obtain the chamber pressure. The background pressure in the chamber was set at Po $=8 \times 10^{-5}$ Torr with the hollow cathode operating. The measured electron number densities ranged between $\mathrm{Ne}=\left(1 \times 10^{4}-8 \times 10^{5}\right)$ per $\mathrm{cm}^{-3}$ or about the same conditions used in the previous bell jar arc spectra experiments [17].

A small solar array test sample (Figure 4) was mounted inside the Teney vacuum chamber and allowed to float in the ambient plasma. The solar array contacts were shorted together and biased over a range of negative bias potentials, $U=-(0.5$ to 1$) \mathrm{kV}$ (See Figure 3$)$. A range of negative potentials was used because the small exposed array contact area, coupled with sample conditioning effects, caused the arc rate to drop over time. The bias potential was continuously adjusted so that an arc rate of about 1 arc per second was achieved for the duration of the tests. Figure 5 features a typical arc on the biased solar array. A quadruple mass spectrometer was employed to monitor the change in partial

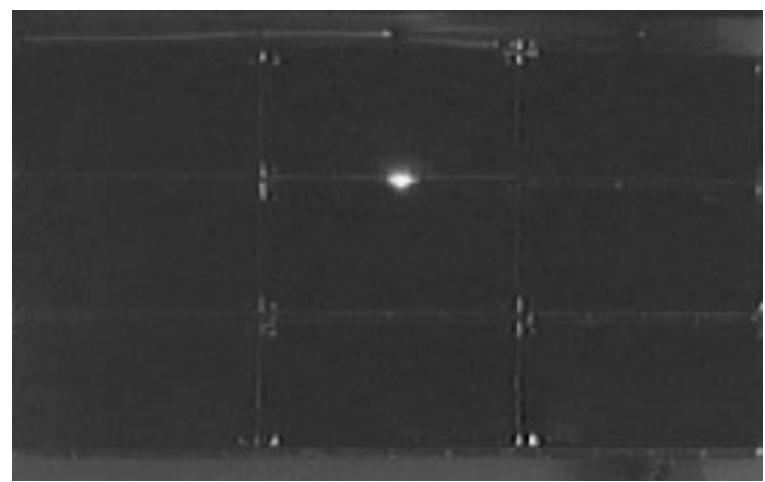

Figure 5: A typical arc on the solar array. $C=1 \mu \mathrm{F}$, bias voltage, $U=500 \mathrm{~V}$.

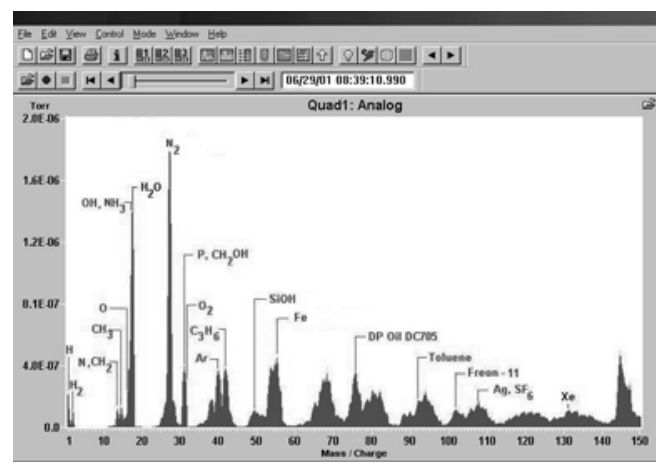

Figure (6a)

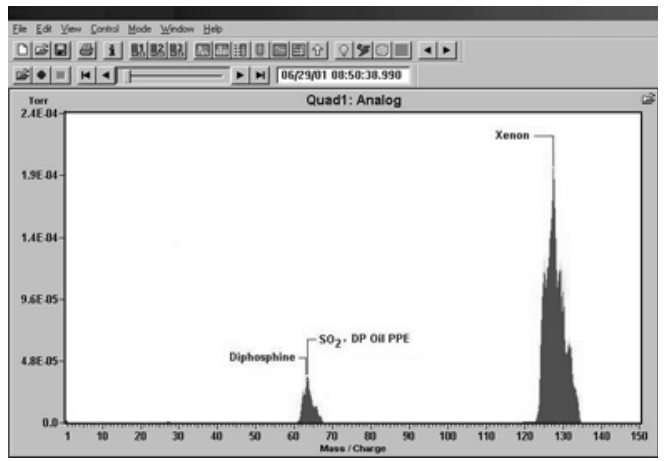

Figure (6b)

Snapshots showing mass spectrum before Figure (6a) and after Figure (6b) xenon gas is introduced into the chamber. 
pressure of several mass species during the arcing process. The solar array sample was mounted a distance of $28 \mathrm{~cm}$ from the feedthrough port of the mass spectrometer (See Figure 3).

\section{Experimental Results}

Figure 6a shows a typical neutral gas background sweep for mass numbers (1-150)
AMU taken in the Tenny vacuum chamber just prior to adding xenon gas. Note the high concentrations of $\mathrm{H}_{2} \mathrm{O}$ and $\mathrm{N}_{2}$ in the vacuum chamber. The concentrations of $\mathrm{H}_{2} \mathrm{O}$ and $\mathrm{N}_{2}$ are approximately a factor of 5 larger in concentration than any other mass species recorded. Figure $6 b$ was recorded just after establishing a constant

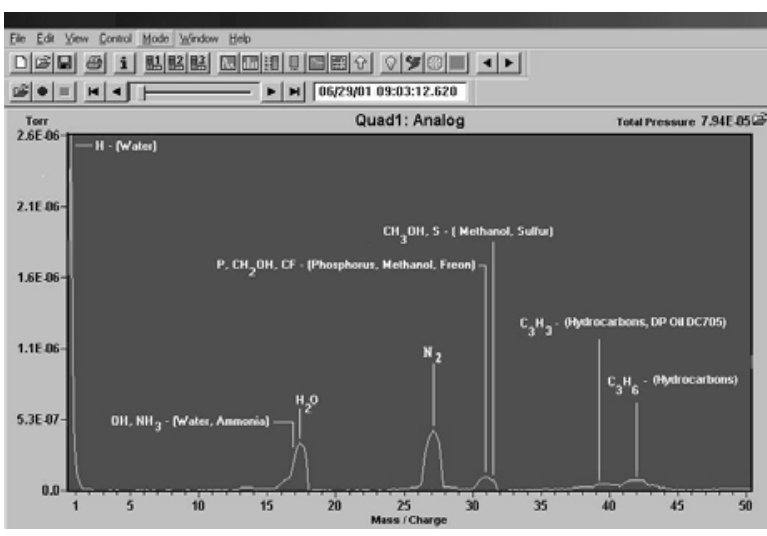

Figure (7a)

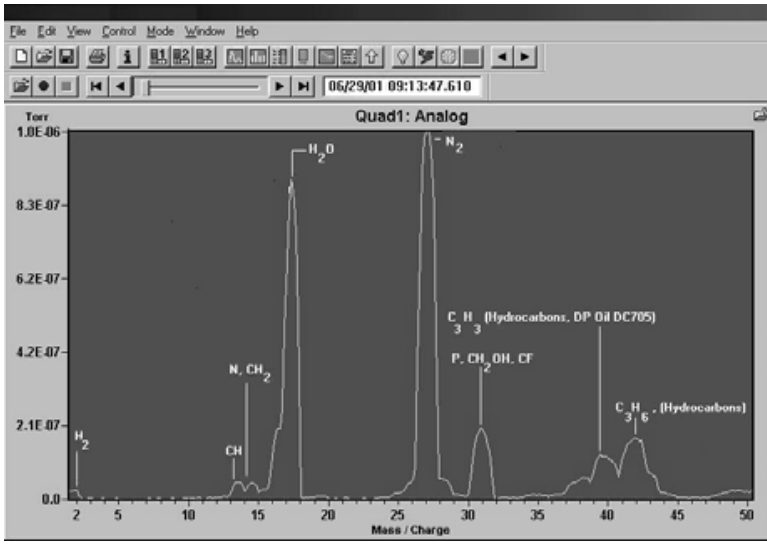

Figure (7b)

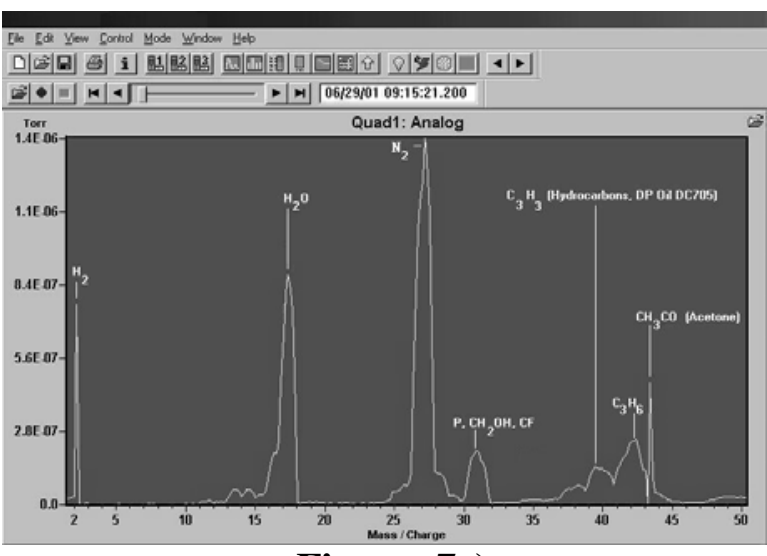

Figure (7c)

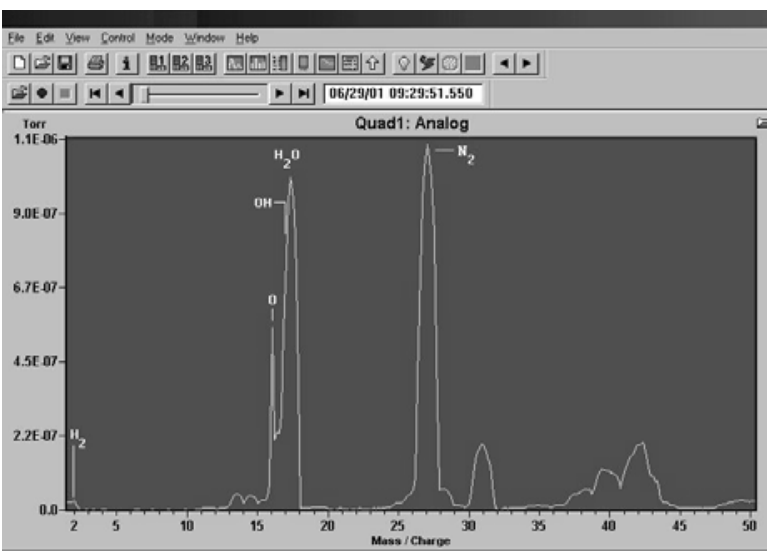

Figure (7d) 


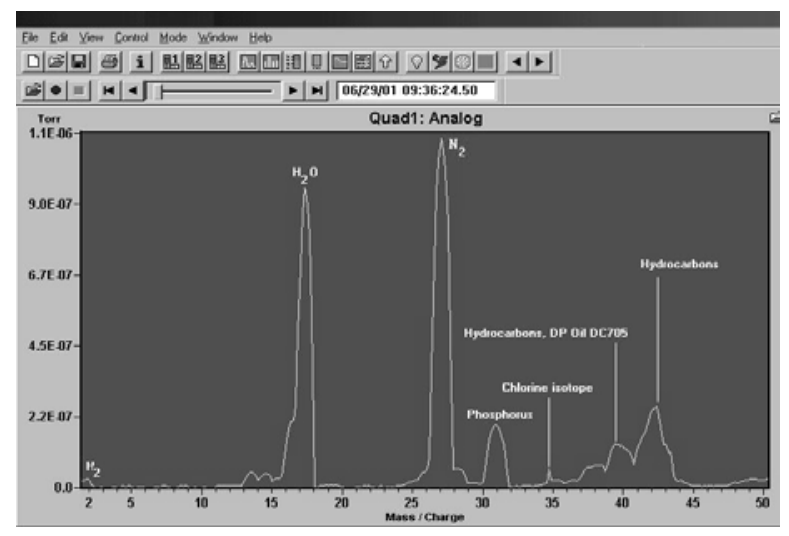

Figure (7e)

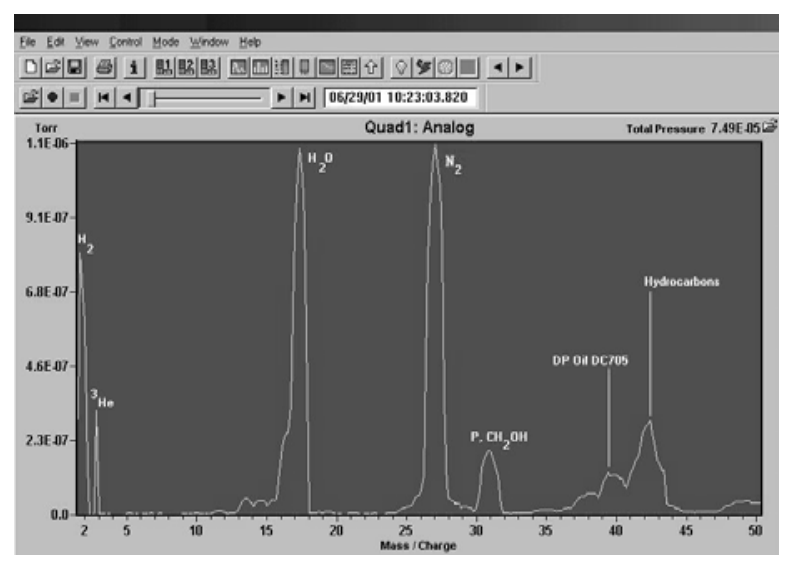

Figure (7f)

xenon flow rate for the hollow cathode. Note that the concentrations of the xenon gas peak and the $\mathrm{SO}_{2}$ peak are large and tend to drive the concentrations of all other mass species in the vacuum system to zero when plotted on this scale. In order to alleviate this problem it was decided to bracket the mass range for all successive sweeps (1-50 AMU and 80120 AMU). Bracketing the mass range also seeks to cut the sweep interval time by less than one half (or just under 60 seconds for 1 complete sweep). Figures $(7 \mathrm{a}-7 \mathrm{~g})$ are snapshots depicting the temporal evolution of the relative concentrations in partial pressure recorded for several mass spectra. The recorded data in Figures $(7 \mathrm{a}-7 \mathrm{~h})$ were obtained with the plasma source operating and the solar array under a large negative potential bias.

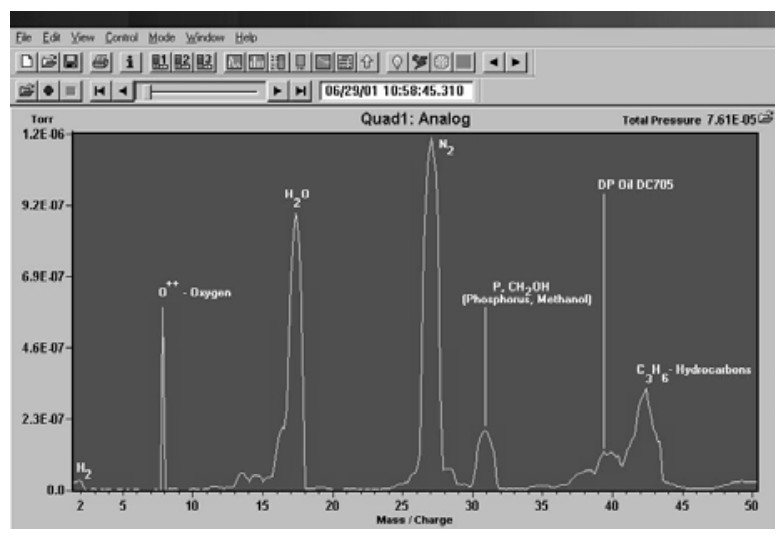

Figure (7g)

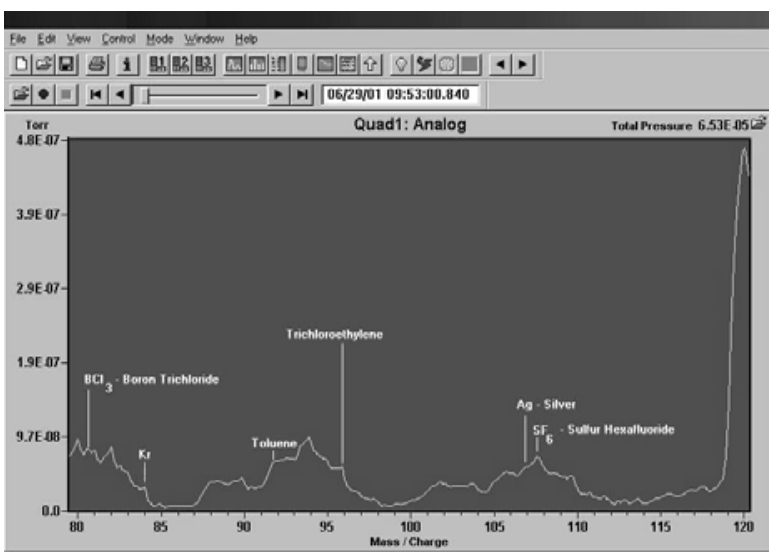

Figure (7h)

Figure $7 \mathrm{a}$ was taken approximately 3.2 minutes after the array was biased. Note the large concentration of hydrogen and the smaller concentrations of $\mathrm{H}_{2} \mathrm{O}$ and $\mathrm{N}_{2}$ in Figure 7a. The snapshot in Figure $7 \mathrm{~b}$ was obtained approximately 10.6 minutes later. Note the increased levels of $\mathrm{H}_{2} \mathrm{O}$ and $\mathrm{N}_{2}$ and the negligible $\mathrm{H}_{2}$ level in Figure $7 \mathrm{~b}$.

Figure $7 \mathrm{c}$ was obtained 1.6 minutes later still (or about 15.3 minutes into the experiment). Note the large spike corresponding to $\mathrm{H}_{2}$. The $\mathrm{H}_{2} \mathrm{O}$ concentration remains about the same level and there is a small increase in the partial pressure of $\mathrm{N}_{2}$ in Figure 7c. The $\mathrm{C}_{3} \mathrm{H}_{3}$ and $\mathrm{C}_{3} \mathrm{H}_{6}$ hydrocarbon concentrations continue to grow in figures $7 \mathrm{a}-$ $7 \mathrm{c}$ but appears to level off after that.

Figure $7 \mathrm{~d}$ was taken 29.6 minutes into the experiment. Note the small concentration in the partial pressure of $\mathrm{H}_{2}$. There appears to be 
a large spike in the oxygen line (mass 16) in Figure 7d. Figure $7 \mathrm{e}$ was obtained 36.4 minutes into the experiment. The mass spectrum in Figure 7e appears to show the vacuum chamber has returned to its typical quiescent arcing state with no remarkable features present. Figure $7 \mathrm{f}$ was recorded 1.4 hours into the experiment. Note the large spikes observed for $\mathrm{H}_{2}$ and the helium isotope, ${ }^{3} \mathrm{He}$. Also note the similar levels in the concentrations of both $\mathrm{H}_{2} \mathrm{O}$ an $\mathrm{N}_{2}$ lines recorded in figure 7f. The snapshot in Figure $7 \mathrm{~g}$ demonstrates a doubly ionized oxygen atom, O III $\left(\mathrm{O}^{++}\right.$, mass 8). Note the decreased level in the partial pressure of $\mathrm{H}_{2} \mathrm{O}$ and the large steady concentration of $\mathrm{N}_{2}$ observed 1 hour and 58.75 minutes into the experiment. Finally the snapshot in Figure $7 \mathrm{~h}$ depicts the typical mass spectrum observed for mass ranges (80-120) AMU. The mass species of the large peak recorded at 119 AMU is unknown.

Figure 8 illustrates the dependence of partial pressure on solar array arcing time for several mass species $\left(\mathrm{N}_{2}, \mathrm{H}_{2} \mathrm{O}, \mathrm{OH}, \mathrm{H}_{2}\right.$ and $\left.\mathrm{O}\right)$ in the vacuum system. The plots were obtained by curve fitting the data to the equation $\mathrm{y}=\mathrm{a}+\mathrm{b} / \mathrm{x}$. (data fits are good to $\mathrm{a}$ factor of $10 \%$ ) Note that the relative levels in the concentrations of all plotted species appear to level off after 1200 seconds or about 20 minutes after the solar array was biased. It is also interesting to note that the plots in Figure 8 are equivalent to plotting partial pressure (of the indicted mass species) against the number of arcs, since the arc rate was adjusted to approximately 1 arc per second throughout the experiment.

\section{Summary}

The presence of adsorbed water vapor at the triple junction sites on a negatively biased solar array is a necessary starting point for evidence supporting a desorbed gas molecular ionization mechanism as the main cause of arc inception. Furthermore we would expect the

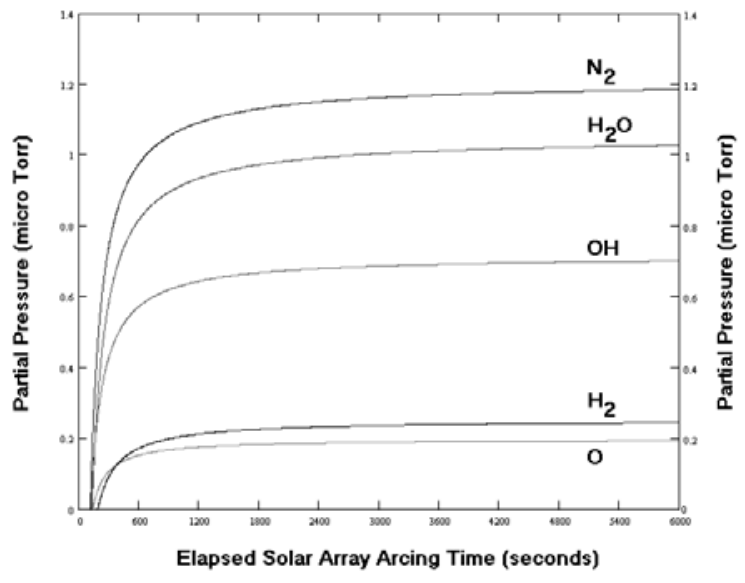

Figure 8: Quadrupole mass spectrometer results for arcs on a biased solar array.

arcing process to drive out water vapor from the triple junction causing increasing the levels of the partial pressure of $\mathrm{H}_{2} \mathrm{O}$ over time. Ionization of the $\mathrm{H}_{2} \mathrm{O}$ by secondary electron emission and subsequent evidence of dissociative recombination processes come from observations of increased levels in the partial pressure of $\mathrm{H}_{2}, \mathrm{H}_{2} \mathrm{O}, \mathrm{OH}$ and $\mathrm{O}$ species over time as graphically illustrated in Figure 8. Note that direct evidence of water vapor at the triple junction was confirmed from earlier spectroscopic observation of the $\mathrm{OH}$ molecular band in solar array arc spectra [17]. Figure 8 demonstrates that $\mathrm{OH}$ species ranks as the third highest concentration of partial pressure recorded in the vacuum chamber.

Dissociative recombination processes tend to occur in very short time intervals (on the order of $10 \mu \mathrm{s})$. Because the acquisition time for 1 complete sweep of mass numbers 1-50 AMU (on the order of 1 minute) is much greater than the dissociative recombination time we would only expect sporadic information at best demonstrated in individual arc spectra. Even so the hydrogen peak in Figure $7 \mathrm{a}$, the oxygen peak in Figure $7 \mathrm{~d}$ and the doubly ionized oxygen $\mathrm{O}^{++}$peak in Figure $7 \mathrm{~g}$ also begin to reveal supporting evidence of a dissociative recombination process occurring. The independent mass spectrometer 
results reported tend to correlate well with earlier spectroscopic observations of the $\mathrm{H}_{\alpha}$ line, the $\mathrm{H}_{\beta}$ line and the $\mathrm{OH}$ molecular band lend even more weight to our hypothesis of a desorbed gas molecular ionization mechanism.

\section{References}

1. Vaughn, J. A., Carruth, M.R., Jr., Katz, I., Mandell, M.J. and Jongeward, G. A., "Electrical Breakdown Currents on Large Spacecraft in Low Earth Orbit", Journal of Spacecraft and Rockets, Vol. 31, No. 1, (1994), p. 54 - 59.

2. McCoy, J. E., and Konradi, A. "Sheath Effects on a 100 Meter High Voltage Panel in Simulated Low Earth Orbit, "Proceedings of Spacecraft Charging Technology, (1978) NASA CP-2071, 1978, p. 201-210.

3. Galofaro, J. T., Doreswamy, C. V., Vayner, B.V., Snyder, D. B. and Ferguson, D. C. "Electrical Breakdown of Anodized Coatings in Low-Density Plasmas" Journal of Spacecraft and Rockets, Vol. 36, No.4, July-August (1999), p. 579-585.

4. Carruth, M. R. Jr., Vaughn, J. A., Bechtel, R. T., and Gray, P. A. "Experimental Studies on Spacecraft Arcing" J. Spacecraft and Rockets, 33(3) (1993) p. 323-327.

5. Ferguson, D. C., Snyder, D. B., Vayner, B. V., and Galofaro, J. T. "Array Arcing in Orbit-from LEO to Geo" AIAA paper 99-0218, January 1999.

6. Brunauer, S. "Physical Adsorption" (Princeton University Press, Princeton, N.J., 1945.
7. Somorjai, G.A. "Principles of Surface Chemistry (Prentice - Hall, Englewood Cliffs, N.J., 1972.

8. Diebold, U., and Varga, P., "Determination of Cross Sections for CO Desorption from $\mathrm{Ni}(111)$ induced by $\mathrm{Ar}$ ions at Very Low Impact Energy" Vacuum 41 (1990) p. 210-212.

9. Diebold, U., Moller, W., and Varga, P. "Low-energy Ion Impact Desorption Cross Sections of Carbon Monoxide from Ni(111)" Surface Science 248 (1991) $147-157$.

10. Diebold, U. and Varga, P. "Desorption and secondary ion production during bombardment of $\mathrm{CO} / \mathrm{Ni}(111)$ with $\mathrm{Ne}^{+}$ and $\mathrm{Ne}^{++}$ions at very low impact energies in: Desorption Induced by Electronic Transitions, DIIET IV", Springer Series in Surface Science, Vol. 19, Springer Verleg, Berlin, 1991.

11. Diebold, U., and Madey, T .E. "Absorption and Electron Stimulated Desorption of NH3/IiO2(110)" Journal of Vacuum Science and Technology A 10 (1992), 2327-2335.

12. Draco, R. S., Webster, C. E. and McGilvray, J. M., J. Am. Chem. Soc., 1998, 120, 538.

13. Vayner, B. V., Ferguson, D. C., and Galofaro, J. T. "The Spacecraft Surfaces Degradation and Contamination Caused by Arcing in Low Density Plasmas" Proceedings of XVIVth International Symposium on Discharges and Electrical Insulation in Vacuum" Vol. 2, Eindhoven University of Technology, Eindhoven, The Netherlands, (1998) pp 824-827. 
14. Vayner, B., Galofaro, J. Ferguson, D., Degroot, W., Thomson, C., Dennison, J., and Davies, R, "A Comprehensive Study of Dielectric-Conductor Junctions in Low Density Plasmas", AIAA paper 20020871, 38 ${ }^{\text {th }}$ Aerospace Sciences Meeting \& Exhibit, Jan. 10-13, (2000), Reno, NV.

15. Vayner, B. V., Galofaro, J., Ferguson, D., Degroot, W., and Vayner, L. "Arcing Onset on a Solar Array Immersed in a Low-Density Plasma" AIAA paper 2001-0400, $39^{\text {th }}$ Aerospace Sciences Meeting \& Exhibit, Jan 8-11, (2001), Reno, NV.

16. Vayner, B., Galofaro, J., and Ferguson, D. "Arc Inception Mechanism on a Solar Array Immersed in a Low-Density Plasma" $7^{\text {th }} \quad$ Spacecraft Charging Technology Conference, Noordwijk, The Netherlands, April 23-27, 2001.

17. Galofaro, J., Vayner, B., Degroot, W. and Ferguson, D. “The Role of Water Vapor and Dissociative Recombination Process in Solar Array Arc Initiation" AIAA paper 2002-0938, 40 ${ }^{\text {th }}$ Aerospace Sciences Meeting and Exhibit, Jan. 14-17, (2002), Reno, NV.
18. Hastings, D. E., Cho, M., and Kuninaka, H. "The Arc Rate for a High Voltage Solar Array: Theory and Predictions" J. Spacecraft and Rockets, 29(4), (1992), p 538-554.

19. Cho, M., Miyata, N., and Hikata, M. "Effects of Arcing on Insulator Surface Potential in Plasma: Image Observation" J. Spacecraft and Rockets, 37(1), (2000), p. $150-152$.

20. Cho, M. and Hastings, D. E. "An Analytical and Particle Simulation Study of Semi-Vacuum gas breakdown Phenomena on High Voltage Solar Surfaces in Low Earth Orbit. Phys, Fluid B, 4(8), (1992), p. 2614-2625.

21. Cooke, D. L. and Katz, I. "IonizationInduced Instability in an Electron Collecting Sheath" J. Spacecraft and Rockets, 25(2), (1988), p. 132-138.

22. Ferguson, D. C., Snyder, D. B., and Carruth, R. "Report of the Joint Workshop on Evaluation of Impacts of Space Station Freedom Grounding Configurations", Proceedings of the SOAR90 Conference, Albuquerque, NM, June 26-28, 1990. 
Public reporting burden for this collection of information is estimated to average 1 hour per response, including the time for reviewing instructions, searching existing data sources, gathering and maintaining the data needed, and completing and reviewing the collection of information. Send comments regarding this burden estimate or any other aspect of this collection of information, including suggestions for reducing this burden, to Washington Headquarters Services, Directorate for Information Operations and Reports, 1215 Jefferson Davis Highway, Suite 1204, Arlington, VA 22202-4302, and to the Office of Management and Budget, Paperwork Reduction Project (0704-0188), Washington, DC 20503.

\begin{tabular}{|l|l|l|}
\hline 1. AGENCY USE ONLY (Leave blank) & $\begin{array}{c}\text { 2. REPORT DATE } \\
\text { May } 2002\end{array}$ & $\begin{array}{c}\text { 3. REPORT TYPE AND DATES COVERED } \\
\text { Technical Memoran }\end{array}$
\end{tabular}

\section{TITLE AND SUBTITLE}

May 2002

A Desorbed Gas Molecular Ionization Mechanism for Arcing Onset in

Solar Arrays Immersed in a Low-Density Plasma

6. AUTHOR(S)

WU-755-A4-05-00

J. Galofaro, B. Vayner, D. Ferguson, and W. Degroot

5. FUNDING NUMBERS

8. PERFORMING ORGANIZATION

REPORT NUMBER

National Aeronautics and Space Administration

John H. Glenn Research Center at Lewis Field

Cleveland, Ohio 44135-3191

E-13327

\section{SPONSORING/MONITORING AGENCY NAME(S) AND ADDRESS(ES)}

National Aeronautics and Space Administration

Washington, DC 20546-0001

10. SPONSORING/MONITORING AGENCY REPORT NUMBER

NASA TM-2002-211552

AIAA-2002-2262

\section{SUPPLEMENTARY NOTES}

Prepared for the 33rd Plasmadynamics and Lasers Conference sponsored by the American Institute of Aeronautics and Astronautics, Maui, Hawaii, May 20-23, 2002. J. Galofaro and D. Ferguson, NASA Glenn Research Center; B. Vayner Ohio Aerospace Institute, Brook Park, Ohio 44142; and W. Degroot, Siliconlight, Inc., Sunnyvale, California. Responsible person, Joel Galofaro, organization code 5410, 216-433-2294.

12a. DISTRIBUTION/AVAILABILITY STATEMENT

12b. DISTRIBUTION CODE

Unclassified - Unlimited

Subject Category: 72

Distribution: Nonstandard

Available electronically at http://gltrs.grc.nasa.gov/GLTRS

This publication is available from the NASA Center for AeroSpace Information, 301-621-0390.

\section{ABSTRACT (Maximum 200 words)}

Previous experimental studies have hypothesized that the onset of Solar Array Arc (SAA) initiation in low-density space plasmas is caused by a desorbed gas molecular ionization mechanism. Indeed past investigations performed at the NASA Glenn Plasma Interaction Facility tend to not only support the desorbed gas molecular ionization mechanism, but have gone as far as identifying the crucial molecular species that must be present for molecular ion dominated process to occur. When electrical breakdown occurs at a triple junction site on a solar array panel, a quasi-neutral plasma cloud is ejected. Assuming the main component of the expelled plasma cloud by weight is due to water vapor, the fastest process available is due to $\mathrm{H}_{2} \mathrm{O}$ molecules and $\mathrm{OH}^{+}$ions, or more succinctly, dissociative molecular-ion dominated recombination processes: $\mathrm{H}_{2} \mathrm{O}^{+}+\mathrm{e}^{-} \rightarrow \mathrm{H}^{*}+\mathrm{OH}^{*}$. Recently published spectroscopic observations of solar array arc spectra in ground tests have revealed the well-known molecular $\mathrm{OH}$ band ( 302 to $309 \mathrm{~nm}$ ), as well as the molecular $\mathrm{SiH}$ band (387nm peak), and the molecular $\mathrm{CH}$ band (432nm peak). Note that the $\mathrm{OH}$ band is observed in emission arcs where water vapor is present. Strong atomic lines were also observed for $\mathrm{H}_{\beta}$ at $486 \mathrm{~nm}$ and $\mathrm{H}_{\alpha}$ at $656.3 \mathrm{~nm}$ in prior ground testing. Independent supporting evidence of desorbed gas molecular ionization mechanisms also come from measurements of arc current pulse widths at different capacitances. We will revisit an earlier first order approximation demonstrating the dependence of arc current pulse widths on the square root of the capacitance. The simple arc current pulse width model will be then be used to estimate the temperature of the arc plasma (currently believed to be somewhere in the range of 3 to $5 \mathrm{eV}$ ). The current paper then seeks to extend the outlined work by including numerous vacuum chamber measurements obtained with a quadrupole mass spectrometer. A small solar array was mounted inside the vacuum chamber. A plasma source, also mounted inside the vacuum chamber, is used to simulate a low-density plasma environment. The solar array is then biased to a high negative potential and allowed to arc while a mass spectrometer is used to record the partial pressure of $\mathrm{H}_{2} \mathrm{O}$ and to track other significant changes in mass (1 to 150) AMU.

\section{SUBJECT TERMS}

Solar array arcing; Triple junction; Dissociative recombination process; Mass spectra 15. NUMBER OF PAGES 16

\begin{tabular}{|c|c|c|}
\hline $\begin{array}{c}\text { 17. SECURITY CLASSIFICATION } \\
\text { OF REPORT } \\
\text { Unclassified }\end{array}$ & $\begin{array}{c}\text { 18. SECURITY CLASSIFICATION } \\
\text { OF THIS PAGE } \\
\text { Unclassified }\end{array}$ & $\begin{array}{c}\text { 19. SECURITY CLASSIFICATION } \\
\text { OF ABSTRACT } \\
\text { Unclassified }\end{array}$ \\
\hline
\end{tabular}

